DOI: https://doi.org/10.47264/idea.lassij/4.1.25

Vol. 4, No. 1, (January-June 2020): 293-302

Research Article

URL: https://www.ideapublishers.org/index.php/lassij

\title{
Gender Role as Relative Phenomenon in Bharati Mukherjee's Novel Desirable Daughters
}

\author{
Muhammad Arif ${ }^{1}$, Tayyaba Bashir*2 \& Arshad Mehmood ${ }^{3}$
}

1. Department of English, National University of Modern Languages (NUML), Peshawar, Pakistan.

2. Department of English, University of Kotli, Azad Jammu \& Kashmir (AJK), Pakistan.

3. Department of English, Women University Bagh, Azad Jammu \& Kashmir (AJK), Pakistan.

\begin{abstract}
Gender is a relative, fluid and dynamic phenomenon. In a traditional society woman has always been treated as "other" which needs to be changed. Human beings unconsciously remain engaged to absorb notions of gender-based manhood and womanhood. Gender construction is not static but changes with circumstances. Women who live in different environment face different problems and whole pattern of their lives changes when they change their living conditions and social set up. Gender is basically an aggregate of cultural and sociological traits which are associated with a particular being and leads to marginalization of one gender namely women. A particular behaviour is expected from that gender and vice versa. This concept is visible in the novel 'Desirable Daughters' by Bharati Mukherjee which is primary text for current research. The characters in this novel violate traditional limitations and gender role becomes a fluid and relative concept. So, this work focuses on highlighting that gender role is a relative term primarily a product of environment. The theoretical framework used here is third wave of feminism and the methodology employed to conduct this research is textual analysis.
\end{abstract}

Keywords: Gender Role, Marginalization, Gender Construction, Bharati Mukherjee, Desirable Daughters, Feminism.

\section{Introduction}

Gender role is taken as fixed, rigid and non-changing notion because it has been established/constructed in the society since ancient times and it has been working since centuries. Twentieth century is rich in its thoughts and ideas. One major concept which is product of this century is feminism. Besides other contributions, one significant notion which the theory has attributed is dismantling of defined gender roles of the society. The basic assumption of current research is to highlight this gender demarcations. The research is twofold. First, it targets these defined gender roles and secondly, it nullifies these roles since it is highly a relative concept. The significance of the research lies in the fact that it can be taken as a very central contribution into the field of feminism. It is unique in its approach since it takes gender role from the concept of social construction and holds it to be a mere product of geographical positions.

Gender role has always been a source of conflict. According to major theorists like Beauvoir (1949) and Butler (1990) the concept of gender is constructed one and it is a fabricated notion 
which is inducted to the minds of individuals. In contrast there is "sex" which is biological phenomenon. These two terms are frequently being referred to bring superiority to one particular gender and both these terms are now being rejected by the feminists. The same challenge has its roots in the early feminist movement which stood for the basic rights and then finally in the third wave of feminism, there is reversal of roles. Gender role was considered as a defined phenomenon since the ancient times according to the traditions. This traditional gender divide has had led to a huge gulf between the two genders as systematically divided and fixed to their roles. Current research paper challenges this notion and takes defined roles beyond the traditional gender divide.

To understand the gender role as a relative and fluid trait we need to reconsider the gender itself. Gender is not something based on concrete facts rather it is a constructed phenomenon. The same point is under consideration. Society is not yet ready to accept it because we are sexist and partly because we are obsessed with illogical notion of man domination. The notion has been discussed by Beauvoir (1949) and Butler (1990). Their works focuses on social and historical consideration of women. Beauvoir (1949) in her book Second Sex discuses that women had been subordinated because they have been treated as "other". The notion signifies that they had not been equal part and parallel to man. Thus, the concept of womanhood is just a constructed stance. On the other hand, Butler (1990) is also of the same opinion. She says that gender is a continuous process of construction. Both male and female are continuously engaged in the adoption of their particular traits. Both theorists are of the opinion that gender is not embedded in biology. The biological difference is considered as the cause of superiority and inferiority which is illogical as one is not superior just because of genital.

In order to prove this stance, feminist approach has been chosen to be applied, and main focus of the study is problems of women in traditional societies. When we come to the oppression of women, we actually mean their marginalization and deprivation of their basic human right like in case of any traditional society there are problems like polygamy, young marriages, man domination and limited choices. In order to prove women as the "other" the novel under discussion provides lots of evidences like childhood marriage and the novelist has discussed the character of Tara Chatterjee in the initial chapters. Tara, the bride who is five years old is heeded deep into forest to marry a tree. (p.5).

The incident shows the cruelty and atrocities of patriarchy and the gender biasness as well as the deprivation of women of their due rights. The incident also shows limitation of choices in the case of women, as her consent is not taken though it is going to be the most important decision of her life. Therefore, it is obvious this case that they are taken as the other. The novelist projects at the same time another point that the traditional and ultimate fate of women has to be a wife. The pathetic incidence of the life of the girl is not only that she is going to marry with a tree rather her aunt says to her that she is paying for the sins that she (her aunt) has committed. Thus, she is deprived of a basic human right because of the sin that she has never committed.

The theme of arrange marriages has also been projected by the writer. The arrange marriage is a custom of traditional societies and thus women are particularly left with no option but to accept decisions of their elders. Four marriages have been mentioned by the novelist that are arranged. Among these three are of the tree bride and her sister at the end of $19^{\text {th }}$ century and one of the Tara Chatterjee. First chapter of the novel signifies the pride and determination of Jia Kreshna regarding the marriages who considers himself a modern student and cannot reject 
any theory. His older two daughters have also got married in the young age and hence go for the same decision about the rest.

The case of arrange marriages and limited choices is projected at another occasion, Tara is married to man who was quite strange for her as she says, "I married a man I had never met". The statement shows again the treatment of women as other. She says that her father told her that it was her ripe time to be married (p. 26). The incident shows her dissatisfaction of the marriage and she is totally unaware of the decision. Tara has voiced her annoyance over this and proves to be submissive by taking traditional roles of a daughter and wife.

\section{Literature Review}

A vast literature is available on feminism in general and specifically about the selected novel. It has been explored from various angles. The review of literature provides a very sound background and analysis of the issues as projected by Bharti in the selected fiction.

Shradha (2015: p. 7) in his articles "The Process of Reinventing new Women in Bharti Muhkerjee's Desirable Daughter" talks about significance of the title, "The title of the novel Desirable Daughters (2002) is significant and ironical in treatment of gender issue.". The researcher is of the opinion that condition of women has once been very backward in India. further, it is stated that "She has been at the bottom of social hierarchy in Indian patriarchal set up for a long time; she has been considered as a powerless and weak creature". She describes situation lamenting, "it suggests that daughters are the object of family prestige, so their behaviour should be desirable, that is to stay, in tune with the norms laid by the society and not deviant. Only such daughters who do not cross Laxman Rekha of etiquettes would be liked and appreciated but in the novel two daughters including the protagonist cross the said border". So, the writer has taken a very different approach in the novel.

Gupta (2012) in article "Gender Biases and Resistance in Bharati Mukherjee's Desirable Daughters" talks about the oppression received by the women just because of their gender and says, "Mukherjee depicts the atrocities inflicted on 'gendered subaltern', that is, women in the forms of child marriage, imposed arranged marriage, and limited prospects of career for talented girls like Padma and Tara in the novel". The article highlights major issues as faced by the major character in the selected novel. He further elaborates, "The novelist exposes her disapproval of child marriage and consequent widowhood through intervention of the story of Tree Bride Tara Lata" (Gupta, 2012). The article gives further elaboration of the novel under discussion section.

Bijalwana (2013) article “Bharti Mukherjee's Desirable Daughters: A Theme of Self Versus Society" Through the lives of Tara Lata and her two sisters, author- Bharati Mukherjeecompetently portrays the themes of changing identity, western feminism versus Indian tradition and self-discovery.

Chauhan (2019: p. 5) in her article "A Critical Study of Bharati Mukherjee's Desirable Daughters" explores the fact of the womanhood and is of the opinion, "Tara Chatterje represents the female conscious. She is aware of her desires and expectations. In the particular culture of India, she and her two sisters are expected to remain docile and subservient to the male authority". 
Kumari (2015) in her article "Self-Obsession and reconciliation of Tara in Bharti Mukerjee's Novel Desirable Daughters" refers to life of Tara (the tree-bride) of the novel and opines, "the life of Tara Lata becomes the benchmark to the protagonist of the novel who afterwards also called Tara".

Shah (2017) in her article "Bharati Mukherjee's Craftsmanship in Desirable Daughter" refers Mukerjee's previous novel Jasmine to suggest that migration to America means new opening and freeing the self from the conventional bound society, whereas in Desirable Daughters she considers various patterns of belonging in the global perspective. The tie with homeland and linkage with the past are presented as essential in creating the interstitial place in the host country. Thus, she takes the novel beyond the geographical boundaries.

Lakshmi (2017) in the article titled, "Alienation and assimilation of Tara in Bharati Mukherjee's Desirable Daughters" refers to the life of the daughters in home and, "The three daughters of Bhattacharjee namely Padma, Parvati and Tara are known for their beauty, intelligence, respect, compliance. They are always confined to the four walls of their family" (p. 75). Thus, it is obvious from research that the daughters got a very conventional representation of the lives of the daughters in India.

The above review of the literature gives a detailed account of the available research on the novel under consideration. It gives a vent to the research available and helps find the research gap to study this novel from a very different perspective. The significance of current research is two folds: on the one hand it takes a very unique approach to the text in hand and on the other hand, it also opens new avenues to the future researchers.

\section{Theoretical Framework}

The theoretical framework which is going to be used in the current study is the different theories of feminism and the researcher has primarily taken into consideration the third wave of feminism. The theoretical framework has been super imposed on the ideas of earlier feminists like, the way they started it and consequently linking it to the final stage. It is the phase where theorists take their positions like they completely deny the positions being hold earlier by the patriarchal society. In order to have a comprehensive understanding of feminism we can divide it in three waves.

First wave which started in early $19^{\text {th }}$ century stands for the basic human rights of women like education, life, marriage and right to vote. This wave is often dated back to the publication of A vindication of the rights of women by Marry Wollstonecraft in 1792. This phase is also called classic feminism and its focus is to get right to education. The subjection of women by Mill (1869) also emphasized the women equality and considered marriage as a legal slavery. The motive behind this wave was industrial revolution and liberalism in European politics. This revolution and liberalization in socio-political situation led to the equality between gender and hence to challenge the traditional gender roles.

The publication of Beauvoir's (1949) Second Sex gave a new dimension to conventional study of gender, sex and roles. This wave got momentum in mid 1950s. It challenged traditional patriarchy and resulted in new dimensions. First wave looked for the equality between the genders while this wave emphasized on the socio-political rights of women. Feminist during this stage focused on the issue of treating women as the "other" and unequal part. The real 
strength of this wave was because of its multi dimensions as women of colour and homosexual and other groups also joined the movement.

Third wave started somewhere around 1990s. This wave provided a new path to feminism. It actually got momentum because it was accelerated as reaction to the second wave. The main motive behind this wave was globalization. In $21^{\text {st }}$ century world is like a global village because of technological advancements and internet as the core element of this global village. The movement is in full swing as people; particularly women of different colours can easily contribute to it. The movement focuses on complex power relations. It rejects universal notion of womanhood and gives dignity to diversified groups. Furthermore, the wave also emphasizes to understand power relation, powers associated with a particular gender and to look at the gender role as relative and fluid phenomenon.

\section{Research Methodology}

The methodology which has been used for this research is textual analysis. Textual analysis provides a sufficient space in order to extract inner meanings from a text. It gives a vent to interpret the text in hand as exactly like documenting it so it carries resemblances in the interpretation of the text. Textual analysis is also very spacious with respect to taking into consideration the historical context of any text so the research will look also into historical context of the literary text in hand. Furthermore, it also taking into consideration the nonliterary texts as suggested by Belsey (2005) makes the method bricoleur in nature.

This research has taken into consideration the intertextual method since, without referring to intertextual the analysis of text is not considered an appealing approach (Domindar, 2017). Fitzsimmons (2013) is of the opinion that without intertextual understanding the study is inadequate. The project is relaying on this approach since analysis of the selected texts has been done side by side. It draws a point of comparison on the basis of similarities in both the texts so that to formulate a strong conclusion.

Intertextuality provides a ground to any text in any particular context. Fairclough (2003: p.14) states that "intertextuality is a matter of recontextualization.". It gives an opportunity to a reader to take any text from one context to another as mentioned by Linell (1998: p.15) claims, "recontextualization can be defined as, "dynamic transfer-and-transformation of something from one discourse/text-in-context ... to another". So, it is a matter of changing the context of any narrative in order to bring it to some/another one which enriches the meaning of the text and takes the text away from any particular social and political condition. I have tried to analyze the selected texts on the basis of their similarities.

\section{Analysis and Discussion}

In order to analyze the gender roles in the novel under consideration the approach of Beauvoir (1949) and Butler (1990) are being implied. The text of the novel and selected quotation would provide sufficient evidences to prove the gender roles as a relative phenomenon. The analysis would further show that women have been treated as the "other" and hence been marginalized. Society and culture further shrink the roles and choice for both the genders. Furthermore, the gender role is a process of continuous construction and gender is a performance not inherited in gens. Thus, it has neither origin nor concrete base. 
Beauvoir (1949) in her work The Second Sex discusses that women have always been taken as inferior as well as an unequal part and are always treated unjust. One unjust treatment is that the father of bride is burdened with heavy dowry. He is given a low status, as an example the novelist portrays insulting attitude of father of the dead bridegroom since he conveys a very insulting message to the family of the bride. Thus, women are always stuck in the clutches of the male dominated society as their father and brother(s) has to surrender keeping all his pride aside. therefore, it is not only the women who is oppressed rather they are made curse for the whole family in the society.

The family of the bridegroom is given high status just because they are associated with man. Thus, the domination of man is a kind of cluster of traits which give him preference over woman. There is an example of the dowry, male counterpart is considered as superior in this context also as the father of bridegroom says, "you will arrange post-haste for the dowry cash and the dowry gifts to be brought on board, Jia Kreshna babu. What you do with your wretched girl, the killer of my son, I make your business" (p.13). Thus, they exploit the family of bride to the possible extent as they demand heavy dowry though the marriage has not yet done. Furthermore, the girl is called as wretched and the killer of their son and is considered as the cursed creature.

The question of male domination is not limited to economic position rather it is process of internalization. Thus, if the roles are supposed to be changed, it cannot be changed just because of challenging the economical pattern. It is a kind of complex power relation thus if there is any misfortune on the part of both the parties the root cause was used to be the woman. Hence, the bride is given the inferior status and she is blamed for the mishap as Tara and the Treebride were blamed because their bridegrooms were bitten by snakes. The father of the bride in the novel pleads for their uncommitted sin to the father of the bridegroom saying, "please tell me what pain we have inadvertently inflicted" (p.11). This example shows that how much the women along with her relatives are oppressed and mentally tortured just because of their association with her.

The ideas of Beauvoir (1949) show that women have no individual identity in the family or in the society. They suffer from identity crises and get their identity in connection to their male counterparts and their existence is at threat if taken individually. Women in the traditional society take role as daughter and wife and have to follow the commands of father and consequently the commands of husband if she goes to her in law's house. She is taken as alien without husband. Jai Kreshan is worried about his daughter as he says, "his daughter's true fate, the fate behind her horoscope, had now been revealed" (p.14). Similarly, there is evidence in chapter one that shows that woman role primarily is to be as we observed that Kreshna marries off his daughter to a tree.

The same notion has been raised by Nayer (2008) that traditional role of a woman in traditional society is to be a wife and to look-after the household affairs. Marriage and motherhood are considered essential tasks to be performed by women. Furthermore, as we discussed earlier that a woman has no individual identity and she primarily gets her existence and identity in connection to man. If woman is alone, divorced or unmarried she becomes an easy prey. Thus, she is always at threat and has no security and always depends on man for her existence. This pathetic picture has been given by Tara when she is divorced as she says that after divorce everyone in her social circle started to avoid her, though she did not expect from them (pp. 188-189). She is left even by her closest friends. 
Besides the problems that women in the traditional society face, there is problem of constrains of choices. This notion has been discussed by Butler (1990) in her book Gender Trouble. She elaborates how gender is kept under heavy trouble by keeping the choices very limited. These limitations are brought at lower as well as higher levels and when we challenge these points, we actually challenge power relation. We are not ready to accept relativity of gender roles hence it brings problems in our daily lives.

The choice of limitation is evident in chapter two of the novel where Tara's father is not ready to accept turning down movie offer. This led to her cut off from political situation inside Calcutta. Though their world was at last verge, they were totally ignorant. Tara Chatterjee considered the constricted world of her house as secure. On the other hand, we looked Padma's wish to be a film star is confined by her father by denying her wish. Thus, not only Padma is affected by the decision of her father, but Tara is also equally influenced as she says that her sister was a new girl, but her father destroyed her (p. 179). The above examples show limitation of women choices and hold of patriarchy.

Geetha has discussed in detail the roles performed by both males and females. She is of the opinion that masculine and feminine roles are relevant in the sense that society expects the same thing from them. Society puts them in a specific design and the same design is indoctrinated hence we follow it unconsciously. As gender is component of a super structure so the inferior component is unconsciously depressed and marginalized. Here is the case of the elder sister Parvati who was supposed to be married first. If she were not married first, then it was a message that her father was not able to control her. Her love affair led to her denial by the male counterpart as there was a rumour of her pregnancy. Thus, the role which has been designed by the society they have to follow that otherwise it was going to be considered as challenging the patriarchy.

The individual roles are designed by the society and there is no biological or an inherent root cause of this phenomenon. Therefore, we see the same character Tara as a transformed person with different characteristics when she moves to America. There she gets liberty and is out of the confined and limited role assigned to her by traditional society. She describes herself as Cole Valley with her son Rabi and is engaged in volunteer work in a preschool two block ways. This independence and raising her child leads to subversion of gender role as she says, "It's one of those San Francisco things I can't begin to explain in India, just like I can't explain my Indian life to the women know in California". The example shows the relativity and subversion of gender roles of both man and woman. The protagonist Tara is living with her lover as a divorced women and this concept cannot be imagined in the Indian society. Nayak and Jeevan discuss status of divorced women in Indian community that they have no other option than Sambandhan. Furthermore, they are of the opinion that divorce is a kind of tragedy and misfortune. Tara considers it as failure of institution of marriage as she says, "in America, it seemed to us, every woman was expected to create her own scandal, be the centre of her own tangled love nest" (p. 83)

Butler's idea (1990) of gender role is also not much different as she is of the opinion that it is construction of law, practices and institution. That is the cause that we found Tara as a quite different character during her stay in America. She has totally transformed into American life and their women. To make this point much clear we have another example from the second chapter of the novel. We see that in America, women have liberty to live independently and do 
not need protection of men. Same is the case with Tara when she moves there, she is totally independent and lives alone.

Beauvoir (1949) holds that women are not supposed to be engaged only in the domestic activities of their household. The traditional roles are of fluid nature and can be reversed. The novel under discussion gives a clear notion of the changed gender roles in chapter eleven from the life of Padma and her husband Harish who have transformed their roles in America. The fact is told by Tara that the coming back of the Harish is a signal that he would appreciate beauty and stamina of his wife. After this he pours juice into Dixie cups for them and they leave for living room while Harish is busy in cooking meal for them. The same thing is being referred by Padma when she asks from Tara that how many families she knows where the wife goes for work outside and the husband stays at home (p.182). Tara than tells root cause of this changed gender roles. She says that according to the situations and the needs of modern America these roles can be reversed as they have no concrete bases. The same thing has also been explained by Judith who is of the opinion that now the boys and girls are getting same education and jobs.

Women of post-feminist era are expected to make their choices and are beyond limited roles that are assigned to them by the family and society. Furthermore, they are supposed to be subjective instead of objective. The status of both the parties are not because of biological or sociological bases rather it is their performance which brings difference. In Desirable Daughters there are many evidences that make the above notions clear like Bride Tara Lata the grand grandmother of Tara. Tara Lata in her childhood was not given choice and was married to a tree but later she becomes more and more independent. It is narrated in first chapter of the novel that Tara Lata, the virgin and the untouched had opened a house first to beggar then to sick and then to the young soldiers fighting the Raj. And it seemed as the crowed Jai Krshna had invited inside the night of the wedding had never left. In this way, Tara Lata becomes saint and the freedom fighter.

The case of Parwati is also not much different. Her approach to life is also very liberal. Incidents from her initial life make it clear that she is not going to be a conventional girl. She wrote a letter to her father stating that she has found a boy and they are both in love (p. 50). This is not a role to be expected from a traditional girl as she is always in clutches of norms but as she has challenged the norms, so she is above all these things and becomes a role model. On the other hand, she rejects the man selected by her father as she tells her sister that she felt disgusted by the names of the boys that her father used to send her (p. 102). Thus, she is beyond the norms, values and traditions.

Butler (1990) is of the opinion that gender identity and performance is the result of a historical treatment of woman. On the other hand, the social condition and family and/or tribe's environment also depend greatly to mould the personality of any individual. Thus, we see these characters with quite different approaches when their social conditions and family environment are changed. They change up to the mark and transform their personalities when they move to America. Tara, the protagonist of the novel complains about her husband when she is living in Bombay as she says, "in India he was more the Indian husband". Thus, we see that not only the female, but also the male characters change their personality when they change their social circumstances. Thus, we can safely assert that one is just a product of society and gender differentiation is a constructed phenomenon which can be reversed with the change in environment and social conditions. 
Gender role is a relative phenomenon and can be reversed. It has no concrete bases and it is a product of society. Women have been historically taken as inferior and an unequal part of society. The feminist movement has led to challenge this idea and to reverse traditional gender roles. Women are no more unequal part of society. Historical treatment, economic conditions and the complex power relations have brought the marginalization of women into existence. They were left with very limited choices like to be wife, mother and to be engaged in the domestic activities. These notions were based on illogical assumption like biological differences and taking woman as weak.

\section{Conclusion}

In the light of above analysis, we can safely assert that inequality between the genders is a kind of myth. Man and woman both have been granted with unlimited potential and it depends on social conditions that to what extent they can materialize their capacities. The novel under discussion shows that both male and female characters change their roles when they change their social set up. The concept about women as "other" is no valid and one is not born what he/she is, and the root cause of the gender inequality is limited choices for the women instead of their incarnated potential. If the environment and the social conditions are changed it would lead to the change of roles and the novel proves it. It is not the genetic issue to be male or female rather is the product of sociological condition and hence, fluid and relative. The research highlights that the roles which have been attached to male or females are just product of society and social set up that we are born in, though very strictly observed. The significance of the research lies in the fact that it opens new dimensions for the upcoming research to look the issues from some other angles.

\section{References}

Beauvoir, S. (1949). The Second Sex. Pantheon.

Belsey, C. (2013). Textual Analysis as a Research Method."

Griffin, G. (2013). Research Methods for English Studies. Edinburgh University.

Bijalwan, R. (2103). Bharati Mukherjee's Desirable Daughters: A Theme of Self versus. New Academia, 2(4), 1-5. http://oaji.net/articles/2014/1439-1416459775.pdf

Butler, J. (1990). Gender Trouble. In: Nicolson, L. Feminism/Postmodernism. Routledge.

Chauhan, S. (2019). A Critical Study of Bharati Mukherjee's Desirable Daughters. BRICS Journal of Educational Research, 9(3-4), 24-25. https://www.bricsjer.com/index.php/brics/article/view/140

Dominadar, L. P. (2017). Inevetibility of Intertextuality Among Literaray Creation. Journal of International Academic Research for Multidisciplinary 9(2), 65-79. https://www.academia.edu/35809795/Inevitability_of_Intertextuality_Among_Liter ary_Creations

Fairclough, N. (2003). Analyzing Discourse: Textual Analysis for Social Research. Routledge. Fitzsimmons, J. (2013). Romantic and contemporary poetry: readings. CQ University ecourses, LITR19049 - Romantic and Contemporary Poetry. http://moodle.cqu.edu.au

Gupta, P. (2012). Gender Biases and Resistance in Bharati Mukherjee's Desirable Daughters. The Criterion: An International Journal in English, 3(4), 2-5. http://www.thecriterion.com/V3/n4/Purnima.pdf

Huggins, N. (1971). Harlem Renaissance. Oxford University. 
Kumari, V. N. (2015). Self-obsession and reconciliation of Tara in Bharati Mukherjee's Desirable Daughters. Review of Research, 4(9), 1-8. http://oldror.lbp.world/UploadedData/1627.pdf

Linell, P. (1998) Discourse across boundaries: On recontextualizations and the blending of voices in professional discourse. Text and Talk, 18(2), 143-158. https://doi.org/10.1515/text.1.1998.18.2.143

Madhavi, P. B. \& Lakshmi, S. S. (2017). Alienation and assimilation of Tara in Bharati Mukherjee's Desirable Daughters. International Journal of English Research, 3(4), 74-76. http://www.englishjournals.com/archives/2017/vol3/issue4/3-4-27

Mill, J. S. (1869). The subjection of women. Longmans, Green, Reader, \& Dyer. https://www.bl.uk/collection-items/the-subjection-of-women-by-j-s-mill

Mukherjee, B. (2002). Desirable Daughter. Rupa.

Nayer, S. (2008). Postcolonial literature. Kindersley.

Shah, M. F. (2017). Bharati Mukherjee's Craftsmanship in Desirable Daughter. Journal of Research in Humanities and Social Sciences, 5(1), 99-101. https://www.questjournals.org

Shradha, S., Dubey, A., \& Vats, S. (2015). The process of Reinventing New Women in Bharti Mukherjee's Deserible Daughters. International Journal of Asian History, Culture and Tradition, 2(1), 1-7. https://www.eajournals.org/wp-content/uploads/TheProcess-of-Reinventing-New-Women-in-Bharati-Mukherjee---s-DesirableDaughters.pdf 